\title{
Erysiphe trifolii Causing Powdery Mildew of Lentil (Lens culinaris)
}

\author{
Renuka N. Attanayake, Department of Plant Pathology, Washington State University, Pullman; Dean A. Glawe, \\ Department of Plant Pathology, Washington State University and College of Forest Resources, University of Wash- \\ ington, Seattle; and Frank M. Dugan and Weidong Chen, USDA-ARS, Washington State University, Pullman
}

\begin{abstract}
Attanayake, R. N., Glawe, D. A., Dugan, F. M., and Chen, W. 2009. Erysiphe trifolii causing powdery mildew of lentil (Lens culinaris). Plant Dis. 93:797-803.

The taxonomy of the powdery mildew fungus infecting lentil in the Pacific Northwest (PNW) of the United States was investigated on the basis of morphology and rDNA internal transcribed spacer (ITS) sequences. Anamorphic characters were in close agreement with descriptions of Erysiphe trifolii. However, teleomorphs formed chasmothecial appendages with highly branched apices, whereas E. trifolii has been described as producing flexuous or sometimes loosely branched appendages. Branched appendages have been described in Erysiphe diffusa, a fungus reported from species of Lens, Glycine, and Sophora, raising the possibility that the PNW fungus could be $E$. diffusa. Examination of morphological characters of an authentic specimen of $E$. trifolii from Austria determined that it included chasmothecial appendages resembling those seen in PNW specimens. Furthermore, ITS sequences from five powdery mildew samples collected from lentils in PNW greenhouses and fields from 2006 to 2008 were identical to one another, and exhibited higher similarity to sequences of E. trifolii (99\%) than to those of any other Erysiphe spp. available in GenBank. Parsimony analysis grouped the lentil powdery mildew into a clade with Erysiphe baeumleri, E. trifolii, and E. trifolii-like Oidium sp., but indicated a more distant relationship to $E$. diffusa. In greenhouse inoculation studies, the lentil powdery mildew fungus did not infect soybean genotypes known to be susceptible to E. diffusa. The pathogenicity of $E$. trifolii on lentil was confirmed using modified Koch's postulates. This is the first report of E. trifolii infecting lentil. E. diffusa and E. trifolii have different host ranges, so the discovery of E. trifolii on lentil has implications both for determining species of powdery mildews on coolseason grain legumes, and in disease management.
\end{abstract}

Lentil (Lens culinaris Medik.) is a staple food crop in many developing countries. In the United States, lentil is an important rotational crop in cereal-based production systems in the Pacific Northwest (PNW) and in the Northern Great Plains. The crop faces several major biotic stresses which limit yield, including Ascochyta blight (caused by Ascochyta rabiei (Pass) Labr.), Botrytis gray mold (caused by Botrytis cinerea Pers. ex. Fr.), Fusarium root rot (caused by several Fusarium spp.), and Rhizoctonia root rot (caused by Rhizoctonia solani Kühn) $(5,24)$.

Powdery mildew of lentil has been reported from various parts of the world including South Asia, the Middle East, the Mediterranean, East Africa, Eastern Europe, the former USSR, South America, and more sporadically, from North America (1). Although usually a minor disease, it can be severe on certain lentil cultivars and in some parts of the world, particularly

Corresponding author: Weidong Chen

E-mail: w-chen@wsu.edu

Accepted for publication 14 April 2009.

doi:10.1094/PDIS-93-8-0797

This article is in the public domain and not copyrightable. It may be freely reprinted with customary crediting of the source. The American Phytopathological Society, 2009. in India during January and February (1). Powdery mildew has been a persistent disease problem of lentil breeding materials in the greenhouse (6), and poses a threat to precious lentil breeding materials such as F1 plants.

Erysiphe pisi DC. is the powdery mildew pathogen that has been reported (often as E. communis auct. or E. polygoni auct.) on lentil from various parts of the world including Argentina, Chile, India, Italy, Jordan, Mexico, Romania, Sudan, Tanzania, and the former USSR $(3,12,15)$. Leveillula taurica (Lév.) Arnaud has been reported from the former USSR (15). The species of Erysiphe attacking lentil often has been unclear, and some reports refer only to Erysiphe sp. or Oidium sp. $(3,15)$. Recently, Erysiphe diffusa (Cook \& Peck) U. Braun \& S. Takam. was reported (as Microsphaera diffusa Cook \& Peck) infecting lentils in Canada (4). The species name was assigned on the basis of dichotomously branched chasmothecial appendages (4).

Infections by Erysiphe species typically result in small white colonies on leaf surfaces. Lesions expand to cover entire leaf surfaces and pods. Mycelial growth and conidial production can be especially extensive at flowering. In the case of severe infections, leaves become chlorotic, then curled and necrotic prior to abscission. Yield decline may occur and plants some- times die (1). Infection by L. taurica results in lesions of varying size on leaves and stems, with areas of infection displaying dense, felt-like mycelium.

The taxonomy of the species of powdery mildew infecting lentil in the United States has not been critically examined. This study was initiated to clarify which species of powdery mildew infects lentil in the PNW. Because lentil plants used in genetics and breeding research frequently are grown in greenhouses as well as in fields, this study included comparison of strains in the greenhouse with the lentil powdery mildew occurring in the field.

\section{MATERIALS AND METHODS}

Fungal samples. Seven samples of powdery mildews were used in this study (Table 1). Four samples (LGH06, LGH07, LGH07-119, and LGH N07) were collected from three separate greenhouses during 3 years (2006 to 2008). The greenhouses are separated by a minimum of 500 $\mathrm{m}$. One sample (LSP07) was collected from a lentil field near Pullman, Whitman Co., WA. One sample (Soy08) of powdery mildew from wild soybean (Glycine sp.) was obtained from the USDA Soybean Germplasm Collection at the University of Illinois, Urbana. These samples were used for morphological and molecular studies. An authentic specimen of E. trifolii, WSP 70928, determined by U. Braun and originating from GZU Dupla Fungorum (27), was also used for morphological comparisons.

Morphological characterization. Symptomatic leaves of all the powdery mildew samples were examined under $\times 100$ to $\times 1,000$ using bright field microscopy (Carl Zeiss Model Axioskop 40, Oberkochen, Germany). Morphological characters evaluated included diameter of chasmothecia, chasmothecial appendages, number of ascospores per ascus, and lengths and widths of asci, ascospores, conidia, and conidiophore foot cells. At least 50 measurements for each character were taken per sample for comparison with descriptions of powdery mildew species recorded on lentil $(8,9)$.

ITS sequencing and phylogenetic analysis. Total DNA was extracted from conidia and/or mycelia from infected lentil plants using the FastDNA kit (MP Biomedicals, LLC, Solon, OH) as described by Chen et al. (11). Polymerase chain reaction (PCR) amplification of the ITS region from each isolate was performed using the 
primers ITS1 and ITS4 (34) or Erysiphespecific primers designed based on conserved sequences of the ITS region of Erysiphe spp. available from GenBank. The Erysiphe-specific primers were EryF $\left(5^{\prime}\right.$ TACAGAGTGCGAGGCTCAGTCG $3^{\prime}$ ) and EryR (5' GGTCAACCTGTGATC CATGTGACTGG $3^{\prime}$ ). The specific primers were helpful in avoiding the amplification of ITS regions of the host plant or other contaminating organisms. PCR reactions in 20- $\mu$ l volume consisted of 2 units of Taq DNA polymerase (Promega, Madison, WI), $1 \times$ PCR buffer, $1.5 \mathrm{mM} \mathrm{MgCl}_{2}$, $0.2 \mathrm{mM}$ dNTPs, $40 \mathrm{ng}$ of the template, and 10 to $20 \mathrm{pmol}$ of each primer, and were subjected to the following temperature parameters: initial denaturation at $92^{\circ} \mathrm{C}$ for $10 \mathrm{~min}$, followed by 35 cycles of denaturation at $94^{\circ} \mathrm{C}$ for $1 \mathrm{~min}$, annealing at $52^{\circ} \mathrm{C}$ for $30 \mathrm{~s}$, extension at $72^{\circ} \mathrm{C}$ for $2 \mathrm{~min}$, and final extension at $72^{\circ} \mathrm{C}$ for $10 \mathrm{~min}$ (BioRad iCycler thermocycler, Bio-Rad Laboratories, Hercules, CA). A negative control without template DNA also was included in each set of PCR reactions.

Amplified DNA fragments were first cloned into plasmid pCR2.1TOPO (Invitrogen Corp., Carlsbad, CA) and transformed into One Shot Topo10 chemical competent cells by following the manufacturer's instructions. Each transformation mixture (50 to $100 \mu \mathrm{l}$ ) was spread and grown on Luria-Bertani (LB) agar plates containing $40 \mu \mathrm{g} / \mathrm{ml}$ of X-Gal (5-bromo4-chloro-3-indolyl-b-D-galactopyranoside) and $50 \mu \mathrm{g} / \mathrm{ml}$ of kanamycin (Invitrogen) for blue-white colony selection. The LB medium contains $10 \mathrm{~g}$ of Bacto tryptone, 5 $\mathrm{g}$ of Bacto yeast extract, $10 \mathrm{~g}$ of $\mathrm{NaCl}$, and
$15 \mathrm{~g}$ of Bacto agar per liter of distilled water ( $\mathrm{pH}$ 7.0). Positive colonies detected by PCR were grown overnight in LB broth containing $50 \mu \mathrm{g} / \mathrm{ml}$ kanamycin at $37^{\circ} \mathrm{C}$. Plasmids were isolated using the Montage life science kit (Millipore Corporation, Bedford, MA) following the manufacturer's instructions. Plasmids containing inserts were further verified by restriction digestion with EcoRI restriction enzyme and separated on $1 \%$ agarose gel. Sequencing reactions were carried out directly with purified PCR product or with isolated plasmids using one of the six primers: EryF, EryR, ITS1, ITS4, M13F, and M13R. Nucleotide sequences were determined from both strands using an $\mathrm{ABI}$ PRISM 377 automatic sequencer (Applied Biosystems, Foster City, CA) at the Sequencing Core Facility of Washington State University. Sequences were used in BLAST searches against the GenBank database (http://www.ncbi.nlm.nih.gov/ BLAST) to identify the most similar sequences available in the databases.

Sequence accessions in the GenBank with high similarity values to the sequences determined in this study were selected for phylogenetic analysis. These included sequences in the species of $E$. baeumleri (Magnus) U. Braun \& S. Takam., E. diffusa, E. pisi, E. trifolii, and Oidium spp. (Table 2). One sequence (AB078807) of E. glycine was used as an outgroup according to Takamatsu et al. (30). Sequences were aligned using the ClustalW program (19). The alignment was refined with a word processing program, and then used in phylogenetic analysis. Phylogenetic analysis was performed using the DNA Parsimony program of the PHYLIP package (16) available at http:// bioweb2.pasteur.fr/phylogeny/intro-en.html. Each nucleotide was weighted equally and each deletion is treated as one step change.

Greenhouse inoculation and pathogenicity assay. Lentil cv. Crimson and two soybean genotypes, L84-2237 (Plant Introduction 547870) and cv. Harosoy (PI 548573), from the USDA Soybean Germplasm Collection at Urbana, IL were planted in the greenhouse. The soybean genotypes L84-2237 and Harosoy are known to be susceptible to $E$. diffusa $(14,21)$. Twenty total lentil plants in five pots (four plants per $15-\mathrm{cm}$ pot) and 16 total soybean plants of each genotype in four pots (four plants per $15-\mathrm{cm}$ pot) were used in the experiment. Three-week-old plants were dusted copiously with conidia collected from infected lentil plants until the young leaves had a white powdery appearance. Plants were maintained in a greenhouse with a 16-h photoperiod, 19 to $23^{\circ} \mathrm{C}$ daytime temperature, $15^{\circ} \mathrm{C}$ at night, and watered daily at the base. Plants were fertilized with nutrient solution (20-10-20 $\mathrm{N}-\mathrm{P}-\mathrm{K})$ twice a week through watering. Relative humidity was not controlled and fluctuated between 25 and 50\%. Development of powdery mildew symptoms as evidenced by white powdery spots was observed and recorded at 2-day intervals for 3 weeks, then at weekly intervals until plants matured. The experiment was repeated once.

The pathogenicity bioassay described by Tiwari et al. (31) was used with some modifications. Seeds of lentil (cv. Crimson) were grown in a separate greenhouse

Table 1. Isolates of powdery mildews used in study

\begin{tabular}{lllcccc}
\hline Isolate & Host & Location & $\begin{array}{c}\text { Year of } \\
\text { isolation }\end{array}$ & $\begin{array}{c}\text { Chasmothecia } \\
\text { production }\end{array}$ & Species & $\begin{array}{c}\text { Embank } \\
\text { accession }\end{array}$ \\
\hline LGH06 & Lentil & Greenhouse 12, Pullman, WA & 2006 & No & Erysiphe trifolii & FJ378883 \\
LGH07 & Lentil & Greenhouse 12, Pullman, WA & 2007 & No & E. trifolii & FJ378876 \\
LGH07-119 & Lentil & Greenhouse 119, Pullman, WA & 2007 & Yes & E. trifolii & FJ378884 \\
LGHN 07 & Lentil & Plant Growth Facility, Pullman, WA & 2007 & Yes & E. trifolii & FJ378882 \\
LSP07 & Lentil & Spillman Farm, Pullman, WA & 2007 & No & E. trifolii & FJ378881 \\
Soy08 & Glycine sp. & Urbana, IL & 2008 & No & E. diffusa & FJ378880 \\
WSP70928 & Melilotus officinalis & Steiermark, Austria & 1984 & Yes & E. trifolii & N/A \\
\hline
\end{tabular}

${ }^{a}$ Greenhouse 12, Greenhouse 119, and Plant Growth Facility are three disconnected greenhouses separated by at least $500 \mathrm{~m}$ located on the campus of Washington State University, Pullman.

b Species identity was determined by Braun $(8,27)$.

${ }^{\mathrm{c}}$ Not available.

Table 2. Sequences used in phylogenetic analysis

\begin{tabular}{|c|c|c|c|c|c|}
\hline Species & Host plant & Isolate & $\begin{array}{c}\text { Country of } \\
\text { origin }\end{array}$ & Sequence accession $^{\mathrm{a}}$ & Reference \\
\hline Erysiphe baeumleri & Vicia amoena & YNMH12360-12 & Japan & AB015933 & Takamatsu et al. (29) \\
\hline E. diffusa & Glycine sp. & Soy08 & USA & FJ378880 & This study \\
\hline E. diffusa & Glycine max & OIGma 10 & Brazil & EF196675 (11) & Almeida et al. (2) \\
\hline E. glycine & G. $\max$ & MUMH1462 (ascomata) & Japan & AB078807 & Takamatsu et al. (30) \\
\hline E. pisi & Lathyrus latifolius & UC1512315 & USA & AF011306 & Saenz and Taylor (26) \\
\hline E. trifolii & Lens culinaris & LGH07-119 & USA & FJ378884 (5) & This study \\
\hline E. trifolii & Trifolium pratense & TPU-1546 & Japan & AB015913 (5) & Takamatsu et al. (29) \\
\hline Oidium sp. (E. trifolii-like) & Vicia faba & MUMH837 & Japan & AB079854 (3) & Okamoto et al. (25) \\
\hline Oidium sp. (E. diffusa-like) & G. $\max$ & MUMH791 & Japan & AB078800 (10) & Takamatsu et al. (30) \\
\hline
\end{tabular}

${ }^{a}$ Number of identical sequences available in GenBank indicated in parentheses. 
where no powdery mildew was detected to obtain powdery mildew-free leaves. Leaves from 14-day-old plants were surface sterilized with $70 \%$ ethanol for $30 \mathrm{~s}$ followed by three serial washings with sterile distilled water (28) and were airdried in a biological safety cabinet. Moist chambers were made with sterile wet filter papers inside sterile 9-cm-diameter petri dishes (33). Trimmed leaf petioles were immersed in sterile $1 \%$ sucrose solution inside a sterile $200-\mu \mathrm{l}$ micropipette tip with its narrow end sealed with a flame. A piece $(4 \times 4 \mathrm{~cm})$ of sterile metal $200-\mu \mathrm{m}$ mesh was kept between the filter paper and the leaf (35) to prevent free moisture formation on the leaf surface, prolonging the greenness of the leaf tissue. Each petri dish setup included one lentil leaf, and leaflets were oriented abaxial surface facing upward. Abaxial surfaces of the leaves were inoculated using a fine paint brush covered with fresh conidia from greenhouse-grown lentil plants until the surfaces were perceptibly tinged with white color (20). The paint brush was disinfected by rinsing in $95 \%$ ethanol followed by air-drying between treatments. Noninoculated (mock inoculated) lentil leaves were kept as controls under the same conditions. Inoculated leaves and controls were incubated at room temperature under white fluorescent light with a 12-h photoperiod (33). Three replicate petri dishes per treatment were used. Powdery mildew symptom development was observed and recorded as presence or absence of powdery mildew pathogen growth for 2 weeks at 2-day intervals using a dissecting microscope. To confirm that the resultant colonies in the pathogenicity assay were caused by the conidia used in inoculation, modified Koch's postulates were carried out. ITS sequences of the resultant colonies were determined and compared with the ITS sequence of the inoculum used in the pathogenicity assay. Small amounts of conidia from each of three leaves in three petri dish trials were used separately for DNA isolation. DNA was released from the conidial samples using the microwave method described by Ferreira and Glass (17) for the limited number of conidia available. About 500 fresh conidia produced on lentil leaves during the leaf bioassay were taken with an inoculation needle or loop and transferred into a 500- $\mu$ l Eppendorf tube. Conidia in the tube were subjected to microwave treatment for $5 \mathrm{~min}$ at the high power (setting of $10,12,000 \mathrm{~W}$ ) in a domestic microwave oven (Kenmore, Elite). A beaker of water was kept inside the oven to absorb microwaves and to protect conidia in the samples from excess dryness. Thirty microliters of TE buffer (10 mM Tris-HCl, $\mathrm{pH} 7.5,1 \mathrm{mM}$ EDTA) was added to the tube, centrifuged at 12,400 RCF for $5 \mathrm{~min}$, and $2 \mu \mathrm{l}$ of the resulting sample was used in $20-\mu \mathrm{l} \mathrm{PCR}$ reaction mixture to amplify the ITS region. Temperature parameters for PCR amplification were the same as above with the exception of annealing at $55^{\circ} \mathrm{C}$ for $1 \mathrm{~min}$. The methods for sequencing PCR products described above for field and greenhouse specimens were followed for DNA sequencing.

\section{RESULTS}

Morphological study. Infected lentil plants from the greenhouse and field initially exhibited symptoms of small white lesions on leaf surfaces (Fig. 1), expanding to cover entire leaf surfaces and pods at the later stages. Mycelial growth and sporula-

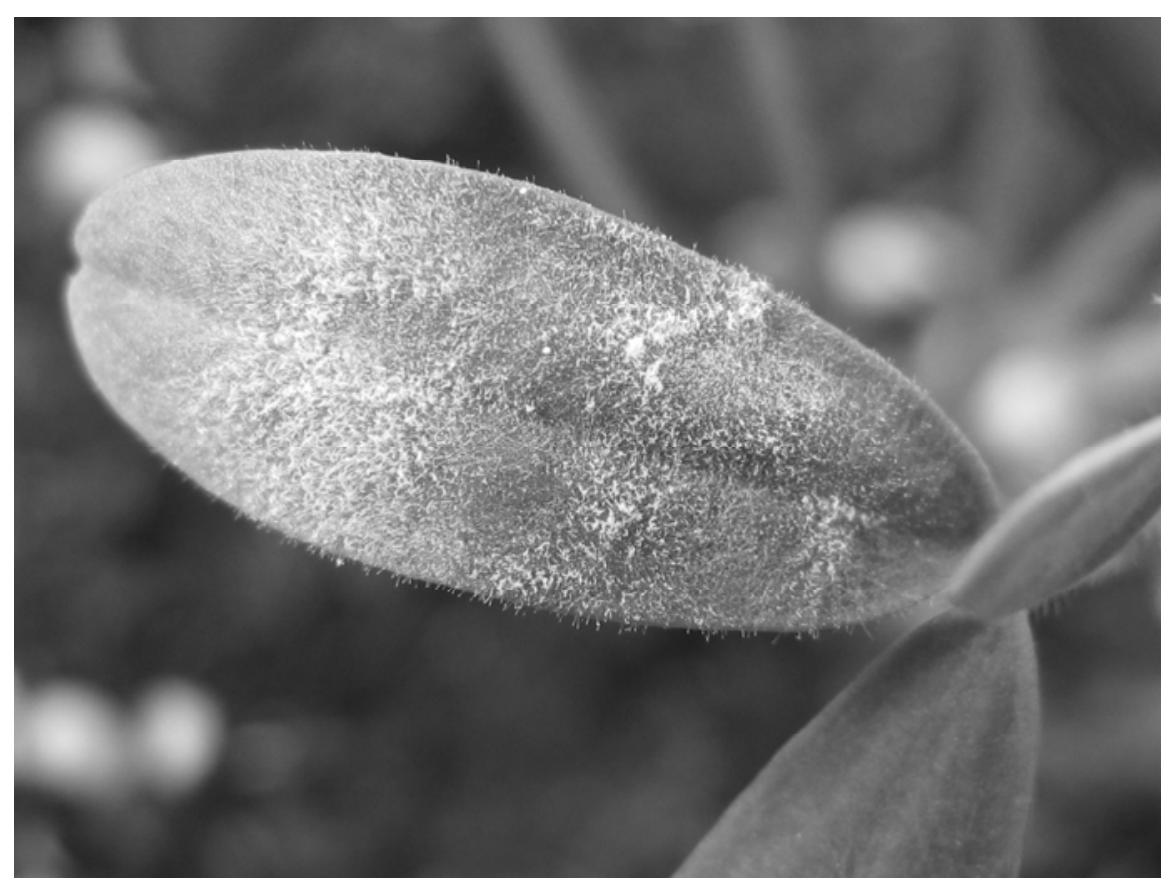

Fig. 1. Powdery mildew symptoms on a lentil leaf showing fresh white powdery growth. tion were especially extensive at flowering. Under severe infection, leaves became chlorotic, then curled and necrotic prior to abscission. Hyaline mycelium was found in scattered patches with abundant production of single, ellipsoid-cylindrical conidia (Fig. 2). Chasmothecia were scattered to gregarious, initially light yellow to tan and turning dark and rusty brown as they approached maturity (Fig. 3). Some chasmothecia were formed in colonies lacking conidia. Chasmothecial appendages were branched 3 to 6 times at the apex; branches were rather loose, diffuse, often deeply cleft with tips that were straight, not curved (Fig. 4). Flexuous appendages were on average 5.5 times as long as the chasmothecial diameters (Fig. 5). Mature chasmothecia contained 3 to 8 asci. Appressoria were lobed. Mature chasmothecia were separated easily from mycelial mats. Morphological characters were compared with those from standard descriptions of Erysiphe species previously recorded on lentils, as well as that for $E$. trifolii (Table 3). Conidia of the powdery mildew sample from a wild soybean (Glycine sp.) were ovoid and measured 28-36 $\times$

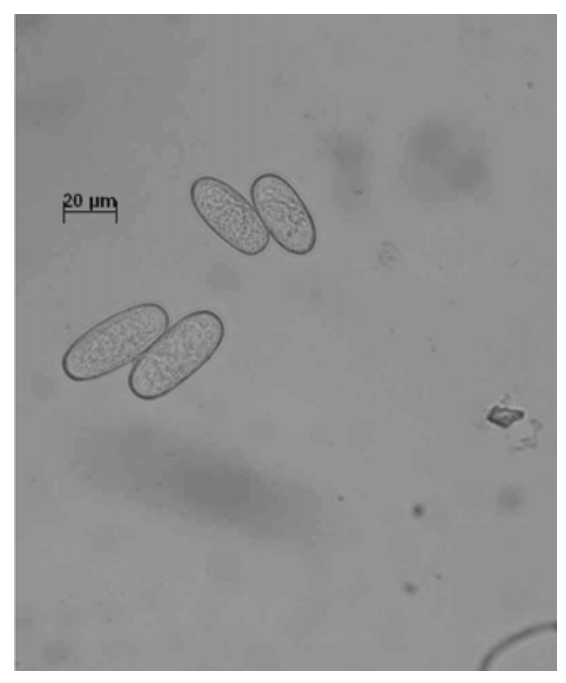

Fig. 2. Conidia of Erysiphe trifolii found on lentil.

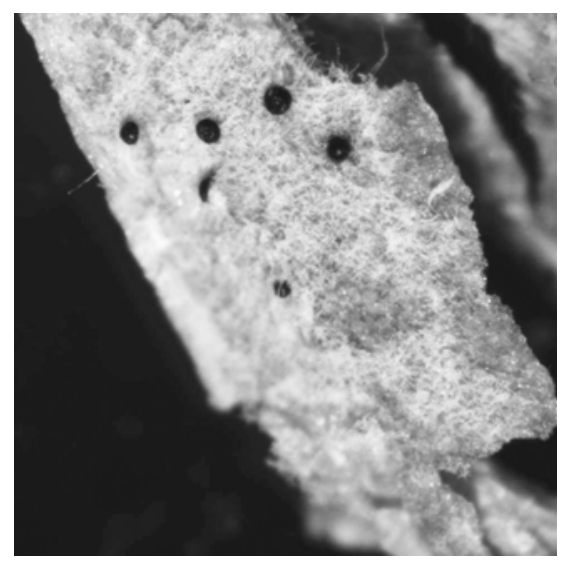

Fig. 3. Chasmothecia of Erysiphe trifolii on a lentil leaf. 
12.5-16 $\mu \mathrm{m}$. No chasmothecia were found on the samples from Glycine sp. The $E$. trifolii herbarium specimen displayed long flexuous chasmothecial appendages (Fig. 6 ), and 10 to $15 \%$ of the appendages were highly branched (3 to 6 times) at their apices (Fig. 7).

ITS sequences and phylogenetic analysis. PCR amplifications were successful with all fresh specimens including the microwave-treated conidia. Amplified products were about $650 \mathrm{bp}$ long. DNA sequences from both strands were obtained. The full length of the ITS region (646 bp) was obtained for all the isolates from lentil, deposited in GenBank, and assigned accession numbers FJ378876, FJ378881, FJ378882, FJ378883, and FJ378884 (Table 1). ITS sequences were identical among all lentil powdery mildew samples. When the complete ITS sequence of lentil powdery mildew was used in a BLAST search, the sequences in GenBank with highest similarity $(99.8 \%$, one basepair difference) were three identical se- quences (AB079853 to AB079855) from E. baeumleri/trifolii-like Oidium sp. from three different hosts from Japan (25). The sequences in the GenBank with next highest similarity $(99.4 \%$, three base pair differences) were five identical sequences (AB015913, AB163926, AB167523, AB167524, and AF298542) from E. trifolii $(13,22,29)$ and a sequence (AB015933) from E. baeumleri (29). The sequence of E. pisi accession AF011306 deposited by Saenz and Taylor (26) exhibited 97\% similarity (14 base pair differences). The ITS sequence of the powdery mildew from wild soybean (deposited with GenBank as FJ378880) had 20 base pair differences (including one-base deletion) from the lentil powdery mildew sequence, and was identical to 21 GenBank sequence accessions (e.g., EF196675 and AB078800) deposited as E. diffusa or Oidium sp. from soybean and lupine from Brazil, Korea, Japan, and the United States (2,30).

The sequence alignment used in the analyses was 584 nucleotides in length.
There were 21 parsimony-informative sites. Parsimony analysis produced one most parsimonious tree with 113 steps. The sequence of lentil powdery mildew formed a single clade (monophyletic) with sequences of Erysiphe baeumleri, E. trifolii, and E. trifolii-like Oidium spp., and was distantly related to (paraphylectic) $E$. diffusa (Fig. 8). The powdery mildew sequence from the wild soybean was identical to and formed a separate clade with $E$. diffusa sequences in the GenBank (Fig. 8).

Greenhouse inoculations and pathogenicity assay. In the greenhouse inoculation studies, visual powdery mildew signs and symptoms started to appear on al inoculated lentil plants 6 days after inoculation, progressing to cover most of the leaves and part of the stems in a 2-week period after inoculation. No powdery mildew signs or symptoms appeared on any of the soybean plants during the entire growth period from the seedling stage to maturity. The same results were obtained in the repeated experiment.

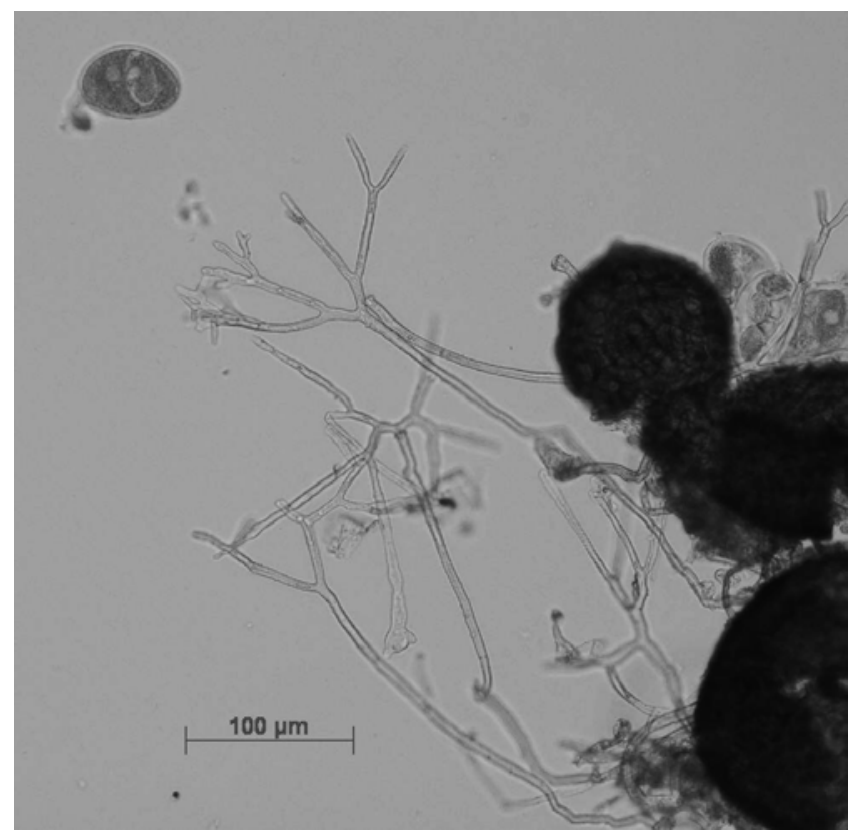

Fig. 4. Terminal branching of chasmothecial appendages of Erysiphe trifolii on infected lentil.

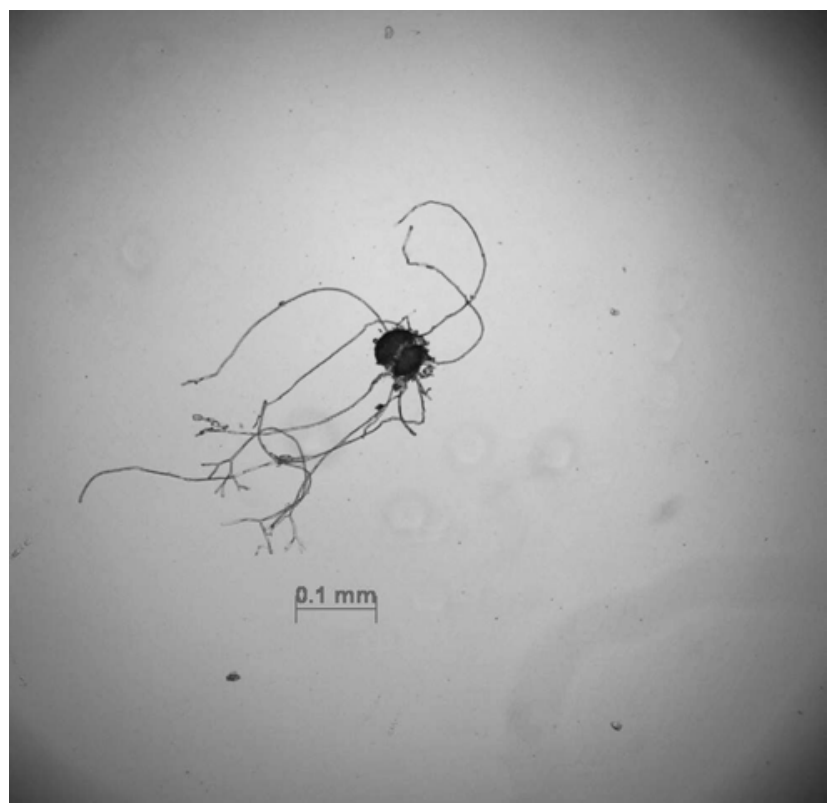

Fig. 5. Long (about 6.5 times as long as the chasmothecial diameter) and flexuous chasmothecial appendages of Erysiphe trifolii on lentil. Branching pattern is visible near the tips of chasmothecial appendages.

Table 3. Morphological characterization of powdery mildew pathogens from lentil and wild soybean, and comparison with Erysiphe diffusa, E. pisi, and E. trifolii as described by Braun $(8,9)$

\begin{tabular}{|c|c|c|c|c|c|}
\hline \multirow[b]{2}{*}{ Character } & \multirow{2}{*}{$\begin{array}{l}\text { Powdery mildew } \\
\text { on lentil }^{\mathbf{a}}\end{array}$} & \multirow{2}{*}{$\begin{array}{l}\text { Powdery mildew } \\
\text { on Glycine sp. }{ }^{\mathrm{a}}\end{array}$} & \multicolumn{3}{|c|}{ Erysiphe species from Braun $(8,9)$} \\
\hline & & & E. pisi & E. trifolii & E. diffusa \\
\hline Conidia length $\times$ width & $25-43 \times 13-22$ & $28-36 \times 12.5-16$ & $24-55 \times 13.5-22$ & $30-45 \times 16-21$ & $25-35 \times 11-17.5$ \\
\hline $\begin{array}{l}\text { Conidiophore foot cell } \\
\text { length } \times \text { width }\end{array}$ & $27-39 \times 7-9$ & $25-33 \times 7.7-9^{b}$ & $(15-) 20-50(-70) \times 6-10$ & $(15-) 25-38(-55) \times 6.5-9$ & $25-38 \times 7.5-10$ \\
\hline Chasmothecia (diam.) & $(78-) 83-130$ & $\mathrm{~N} / \mathrm{A}^{\mathrm{c}}$ & $(80-) 85-150$ & $(80-) 90-150(-180)$ & $75-135$ \\
\hline No. of asci/chasmothecia & $3-6(-8)$ & N/A & $(3-) 4-8(-13)$ & $3-12$ & $4-10$ \\
\hline Ascus (length $\times$ width) & $(46-57-75(-91) \times 40-54(-58)$ & N/A & $40-85 \times 25-55$ & $45-80 \times 25-50$ & $40-75 \times 25-45$ \\
\hline No. ascospores/ascus & $1-5$ & N/A & $(2-) 3-6$ & $(2-) 3-5(-6)$ & $3-6$ \\
\hline $\begin{array}{l}\text { Ascospore (length } \times \\
\text { width) }\end{array}$ & $19-30 \times(9-) 12-19$ & N/A & $(15-) 18-25(-28) \times 10-16.5$ & $(15-) 18-25(-28) \times 10-16.5$ & $16-24 \times 9-15$ \\
\hline
\end{tabular}

\footnotetext{
${ }^{a}$ Data were based on at least 50 measurements unless otherwise indicated, with extreme values in parentheses.

b Data based on five measurements.

c Not available.
} 
In the pathogenicity assay with detached leaves, signs of powdery mildew infection began to be visible 7 days after inoculation. Sizes and shapes of conidia matched those of conidia used for inoculation. No chasmothecia developed on the lentil leaves used for the in vitro pathogenicity test during the 2-week period. Leaves of the mock-inoculated controls remained asymptomatic during the entire period. The ITS region of powdery mildew from all three replicates was successfully amplified with PCR, and two of the samples were sequenced. ITS sequences were identical to the sequence obtained from the conidia from greenhouse lentil plants and used in inoculation.

\section{DISCUSSION}

Several species names have been applied to powdery mildew fungi occurring on lentil. The most commonly reported name is Erysiphe pisi (often reported as E. communis auct. p.p. or E. polygoni auct. p.p.) from various parts of the world $(1,6)$. L. taurica also occurs on lentil (15). Recently, E. diffusa was reported on lentil (4). In this report, we document the occurrence of E. trifolii as a causal agent of powdery mildew of lentil, based on comparison of morphological characters with an authentic specimen of E. trifolii, and parsimony analysis of ITS sequences with those deposited in GenBank by previous researchers. Discovery that E. trifolii can cause powdery mildew of lentil is significant in three aspects: (i) To our knowledge, it is the first report of E. trifolii causing powdery mildew of lentil. (ii) This report broadens the taxonomic concept of $E$. trifolii to include chasmothecial appendages with 3 to 6 times branched apices similar to those reported for $E$. diffusa. (iii) It demonstrates the necessity of close examination of lentil powdery mildew before assuming species identity because the several Erysiphe species reported from lentil occur in differing host ranges and may differ significantly in their epidemiology.

Determination of species names for powdery mildews of legumes traditionally has been based on a few teleomorphic features, including chasmothecial appendage morphology $(8,9)$. However, recent phylogenetic studies demonstrated that anamorphic features are more indicative of phylogenetic lineages than are teleomorphic features, and that anamorphic characters are of utility in species determination $(10,13,18)$. Chasmothecial appendages traditionally used to distinguish genera are now used to help distinguish species (10).

Use of molecular characters, especially ITS sequence data, has given promising results for species determination in some powdery mildews $(2,10,13,30)$. In this study, we used both ITS sequence data and morphological characters to determine the species of the lentil powdery mildew pathogen. Based on the anamorphic characters and ITS sequence data, the pathogen found on lentil was assigned to E. trifolii. However, it frequently displayed highly branched (3 to 6 times) chasmothecial appendages which were more similar to those of $E$. diffusa than to those illustrated for E. trifolii (8). This appendage branching pattern resembles that illustrated for $E$. diffusa f. diffusa, or sometimes even the more intricately branched pattern of $E$. diffusa f. elongata in Braun (8). Considering the length (about 6.5 times as long as the chasmothecial diameter) and flexuous nature of their chasmothecial appendages (which are short and rigid for E. diffusa), these characters for our powdery mildew isolates on lentil plants are in good agreement with E. trifolii (U. Braun, personal communication).

Because E. diffusa was reported from Glycine spp. (2), morphological and molecular characteristics of a powdery mildew specimen from wild soybean were compared to those of lentil powdery mildew. The ITS sequence of wild soybean powdery mildew, with 20 nucleotide differences from the lentil powdery mildew ITS sequence, was identical to 23 GenBank accessions of $E$. diffusa and $E$. diffusa-like Oidium sp. In addition, conidia of the powdery mildew pathogen of wild soybean were in good agreement with those described for E. diffusa (8) and were shorter than those of the lentil powdery mildew pathogen (Table 2). Furthermore, the lentil powdery mildew did not infect soybean genotypes that are known to be susceptible to $E$. diffusa. Close examination of WSP 70928, an authentic specimen of E. trifolii, revealed the presence of $E$. diffusa-like branching pattern on about 10 to $15 \%$ of the chasmothecial appendages. After considering these morphological and molecular characters, the lentil powdery mildew pathogen species in this study was determined to be E. trifolii. It is more like $E$. trifolii than E. baeumleri because of its regular dichotomous branching patterns of the chasmothecial appendages (Fig. 4). E. baeumleri tends to produce irregular branching patterns according to the drawings of Braun (8). Further taxonomic studies and phylogenetic studies would be helpful because $E$. trifolii has been regarded as a complex of similar species

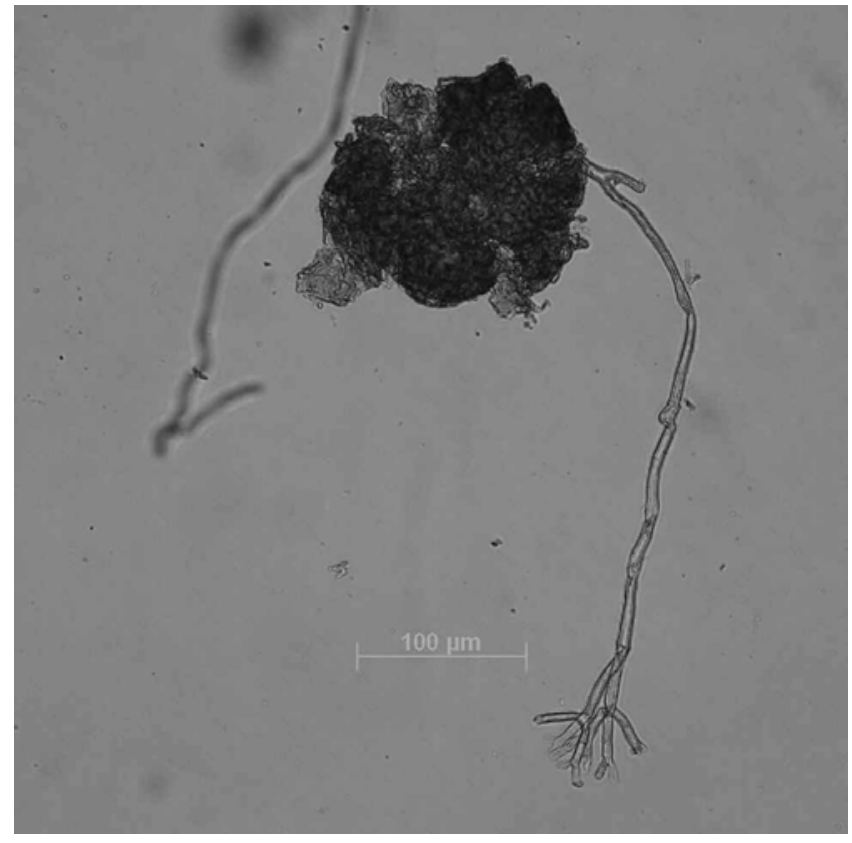

Fig. 6. Long and flexuous chasmothecial appendages of Erysiphe trifolii from the authentic specimen WSP 70928.

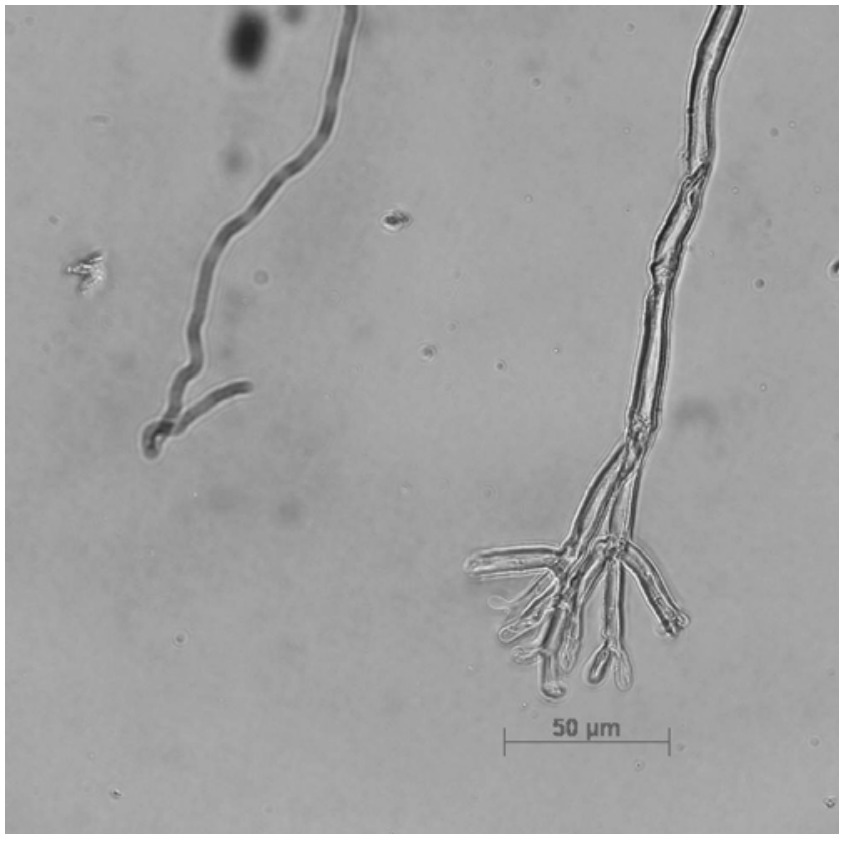

Fig. 7. Branching apices of chasmothecial appendage of Erysiphe trifolii from the authentic specimen WSP 70928. 
consisting of E. trifolii, E. baeumleri, and E. asteragali DC. (8). The nature of this complex is yet incompletely determined (U. Braun, personal communication). It is possible that ITS sequences do not adequately differentiate E. baeumleri from $E$. trifolii, or the two taxa might actually be conspecific (J. Cunnington, personal communication). Given these latter considviously been referenced as the "trifolii" complex, we apply the name E. trifolii to the powdery mildew pathogen of our lentil samples.

Three lines of evidence are presented to document that $E$. trifolii can produce highly branched chasmothecial appendages. First, the powdery mildew samples with branched chasmothecial appendages from lentil yielded ITS sequences with higher similarity values in comparison with ITS sequences from E. trifolii than from $E$. diffusa or other Erysiphe species (Fig. 8); second, anamorphic features are most similar to the descriptions of E. trifolii and differ from those of $E$. diffusa (Table 2); third, the authentic herbarium specimen of $E$. trifolii also contained branched chasmothecial appendages (Figs. 7 and 8). As a result of this study, three Erysiphe species (E. diffusa, E. pisi, and E. trifolii) now are known to infect lentil. $E$. trifolii can be differentiated from $E$. pisi based on long and branched chasmothecial appendages, and E. trifolii can be differenerations, and because these taxa have pre-

tiated from $E$. diffusa by its production of comparatively larger conidia and long, flexuous chasmothecial appendages. In addition, the ITS sequences of the three species differ.

Lentil production is expanding into new areas (23). As a result of the expansion, new diseases or new pathogens may develop on lentil, and previous minor diseases may become economically important. Accurate determination of pathogen species has practical implications in managing the disease. The three species causing powdery mildew on lentil have different host ranges $(3,7,32)$. Knowledge of the pathogen species causing the disease will help in determining cropping sequences and in selecting adjacent crops in managing powdery mildew of lentil.

\section{ACKNOWLEDGMENTS}

We thank Randall Nelson of USDA-ARS, Urbana, IL for providing the powdery mildew specimen on Glycine sp. and soybean seeds, and Uwe Braun of the Hungarian Academy of Sciences, Budapest, Hungary for correspondence concerning the taxonomical status of Erysiphe trifolii. The research was funded in part by the USDA-CSREES Cool Season Food Legume Research Program.

\section{LITERATURE CITED}

1. Agrawal, S. C., and Prasad, K. V. V. 1997. Diseases of Lentil. Science Publishers, Enfield, NH. pp. 59-61.

2. Almeida, A. M. R., Binneck, E., Piuga, F. F., Marin, S. R. R., Riberio do Valle, P. R. Z., and Silveira, C. A. 2008. Characterization of powdery mildew strains from soybean, bean, sun-

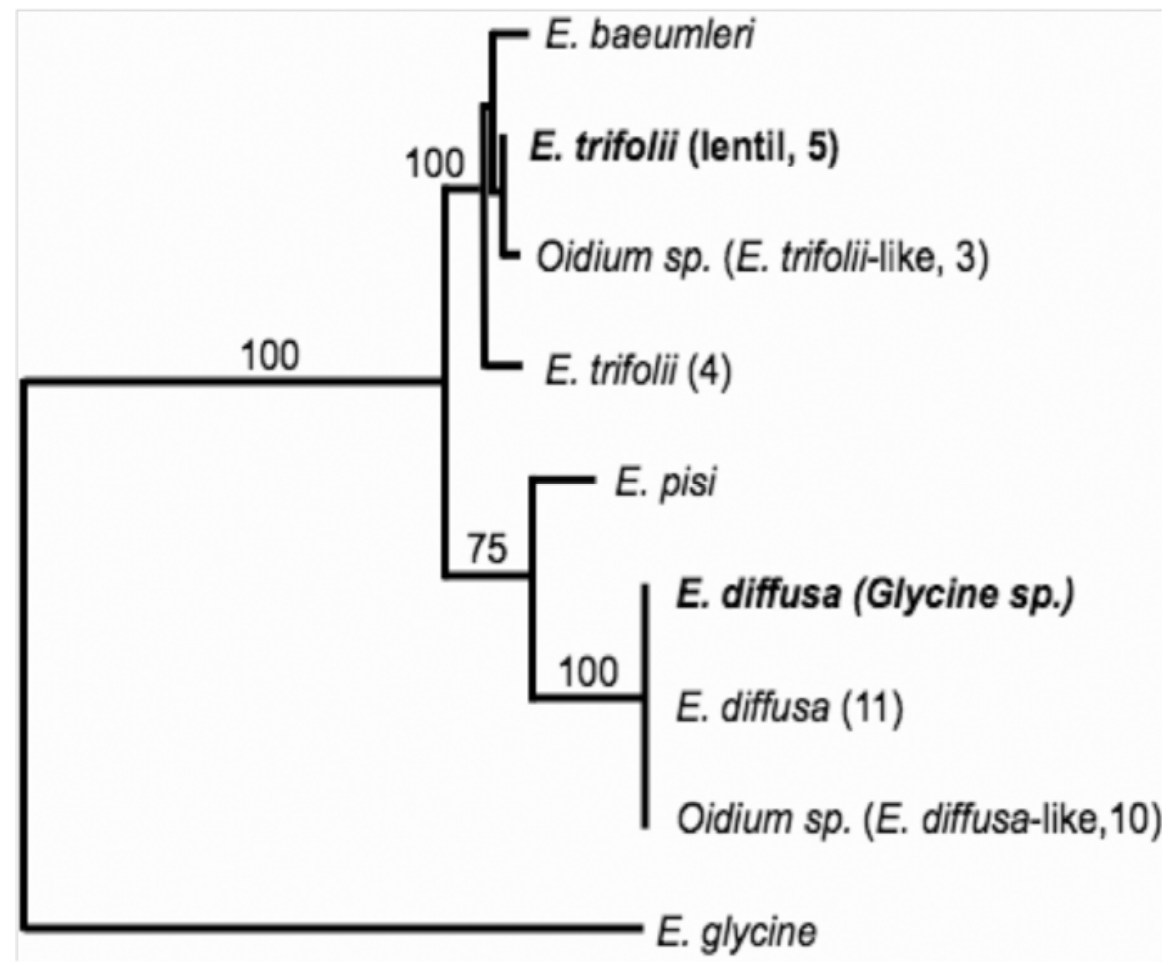

Fig. 8. Parsimony analysis of internal transcribed spacer (ITS) sequences showing close evolutionary relationship of powdery mildew of lentil with Erysiphe baeumleri, E. trifolii, and E. trifolii-like Oidium spp., and distantly related $E$. diffusa. Bootstrap values are indicated for the branches. Bold taxa indicate sequences determined in this study. Numbers of identical sequences in GenBank or in this study are indicated in parentheses. Vertical distances are for clarity and horizontal distances are drawn proportional to number of nucleotide changes. flower and weeds in Brazil using rDNA ITS sequences. Trop. Plant Pathol. 33:20-26.

3. Amano, K. 1986. Host Range and Geographical Distribution of the Powdery Mildew Fungi. Japan Scientific Societies Press, Tokyo. p. 543.

4. Banniza, S., Parmelee, J. A., Morrall, R. A. A., Tullu, A., and Beauchamp, C. J. 2004. First record of powdery mildew on lentil in Canada. Can. Plant Dis. Surv. 84:102-103.

5. Bayaa, B., and Erskine, W. 1998. Diseases of lentil. Pages 423-471 in: The Pathology of Food and Pasture Legumes. D. J. Allen and J. M. Lenné, eds. CAB International, Wallingford, UK.

6. Beniwal, S. P. S., Bayaa, B., Weigand, S. Makkouk, Kh., and Saxena, M. C. 1993. Field Guide to Lentil Diseases and Insect Pests. International Center for Agricultural Research in the Dry Areas (ICARDA), Aleppo, Syria.

7. Bhardwaj, C. L., and Singh, B. M. 1984. Host range of Oidium state of Erysiphe pisi from pea on some leguminous hosts in Kangra valley of Himachal Pradesh. Indian Phytopathol. 37:732-733.

8. Braun, U. 1987. A monograph of the Erysiphales (Powdery Mildews). Beiheft zur Nova Hedwigia 89:1-700.

9. Braun, U. 1995. The powdery mildews (Erysiphales) of Europe. Gustav Fischer Verlag, New York. pp. 1-307.

10. Braun, U., and Takamatsu, S. 2000. Phylogeny of Erysiphe, Microsphaera, Uncinula (Erysipheae) and Cystotheca, Podosphaera, Sphaerotheca (Cystotheceae) inferred from rDNA ITS sequences - some taxonomic consequences. Schlechtendalia 4:1-33.

11. Chen, W., Gray, L. E., Kurle, J. E., and Grau, C. R. 1999. Specific detection of Phialophora gregata and Plectosporium tabacinum in infected soybean plants. Mol. Ecol. 8:871-877.

12. Chitale, K., Tyagi, R. N. S., and Bhatnagar, L. G. 1981. Perfect stage of Erysiphe polygoni on lentil from India. Indian Phytopathol. 34:540541.

13. Cunnington, J. H., Takamatsu, S., Lawrie, A. C., and Pascoe, I. G. 2003. Molecular identification of anamorphic powdery mildews (Erysiphales). Australas. Plant Pathol. 32:421-428.

14. Dunleavy, J. M. 1978. Soybean seed yield losses caused by powdery mildew. Crop Sci. 18:337-339.

15. Farr, D. F., Rossman, A. Y., Palm, M. E., and McCray, E. B. (n.d). Fungal Databases, Systematic Mycology and Microbiology Laboratory, ARS, USDA. Retrieved January 23, 2008, from http://nt.ars-grin.gov/fungaldatabases/

16. Felsenstein, J. 1989. PHYLIP - Phylogeny Inference Package (Version 3.2). Cladistics 5:164-166.

17. Ferreira, A. B., and Glass, N. L. 1996. PCR from fungal spores after microwave treatment Fungal Genet. Newsl. 43:25-26.

18. Glawe, D. A. 2008. The powdery mildews: A review of the world's most familiar (yet poorly known) plant pathogens. Annu. Rev. Phytopathol. 46:27-51.

19. Higgins, D., Thompson, J., Gibson, T., Thompson, J. D., Higgins, D. G., and Gibson, T. J. 1994. CLUSTAL W: Improving the sensitivity of progressive multiple sequence alignment through sequence weighting, positionspecific gap penalties and weight matrix choice. Nucleic Acids Res. 22:4673-4680.

20. Lim, T. M. 1973. A rapid laboratory method of assessing susceptibility of Hevea clones to Oidium heaveae. Exp. Agric. 9:275-279.

21. Lohnes, D. G., and Nickell, C. D. 1994. Effect of powdery mildew alleles $R m d-c, R m d$, and rmd on yield and other characteristics in soybean. Plant Dis. 78:299-301.

22. Matsuda, Y., Sameshima, T., Moriura, N., Inoue, K., Nonomura, T., Kakutani, K., Nishimura, H., Kusakari, S., Takamatsu, S., and Toyoda, H. 2005. Identification of individual 
powdery mildew fungi infecting leaves and direct detection of gene expression by single conidium polymerase chain reaction. Phytopathology 95:1137-1143.

23. Miller, P. R., McConkey, B. G., Clayton, G. W., Brandt, S. A., Staricka, J. A., Johnston, A. M., Lafond, G. P., Schatz, B. G., Baltensperger, D. D., and Neill, K. E. 2002. Pulse crop adaptation in the Northern Great Plains. Agron. J. 94:261-272.

24. Morrall, R. A. A., McKenzie, D. L., Duczek, L. J., and Verma, P. R. 1972. A qualitative survey of diseases of some specialty crops in Saskatchewan in 1970 and 1971: Sunflower, safflower, buckwheat, lentil, mustards, and field pea. Can. Plant Dis. Surv. 52:143-148.

25. Okamoto, J., Limkaisang, S., Nojima, H., and Takamatsu, S. 2002. Powdery mildew of prairie gentian: Characteristics, molecular phylogeny and pathogenicity. J. Gen. Plant Pathol. 68:200-207.

26. Saenz, G. S., and Taylor, J. W. 1999. Phylogeny of the Erysiphales (powdery mildews) inferred from internal transcribed spacer ribo- somal DNA sequence. Can. J. Bot. 77:150168.

27. Scheuer, C. 2003. Dupla Fungorum, Supplementum (2003), verteilt vom Institut für Botanik der Universität Graz (GZU). Fritschiana (Graz) 40:1-51.

28. Spurr, H. W. 1979. Ethanol treatment: A valuable technique for foliar biocontrol studies of plant disease. Phytopathology 69:773-776.

29. Takamatsu, S., Hirata, T., Sato, Y., Nomura, Y., and Sato, Y. 1999. Phylogenetic relationships of Microsphaera and Erysiphe section Erysiphe (powdery mildews) inferred from the rDNA ITS sequences. Mycoscience 40:259268.

30. Takamatsu, S., Shin, H. D., Paksiri, U., Limkaisang, S., Taguchi, Y., Nguyen, T.-B., and Sato, Y. 2002. Two Erysiphe species associated with recent outbreak of soybean powdery mildew: Results of molecular phylogenetic analysis based on nuclear rDNA sequences. Mycoscience 43:333-341.

31. Tiwari, K. R., Penner, G. A., Warkentin, T. D., and Rashid, K. Y. 1997. Pathogenic variation in Erysiphe pisi the causal organism of powdery mildew of pea. Can. J. Plant Pathol. 19:267-271.

32. Tiwari, K. R., Warkentin, T. D., Penner, G. A., and Menzies, J. G. 1999. Studies on winter survival strategies of Erysiphe pisi in Manitoba. Can. J. Plant Pathol. 21:159-164.

33. Warkentin, T. D., Rashid, K. Y., and Zimmer, R. C. 1995. Effectiveness of a detached leaf assay for determination of the reaction of pea plants to powdery mildew. Can. J. Plant Pathol. 17:87-89.

34. White, T. J., Bruns, T., Lee, S., and Taylor, J. 1990. Amplification and direct sequencing of fungal ribosomal RNA genes for phylogenetics. Pages 315-322 in: PCR Protocols: A Guide to Methods and Applications. M. A. Innis, D. H. Gelfand, J. J. Sninsky, and T. J. White, eds. Academic Press, San Diego.

35. Zhang, R., Hwang, S., Chang, K., Gossen, B. Strelkov, E., Turnbull, G., and Blade, S. 2006. Genetic resistance to Mycosphaerella pinodes in 558 field pea accessions. Crop Sci. 46:2409 2414 